\title{
Feminist criminology and technopolitics: New frames for gender- based violence in Brazil
}

OÑATI SOCIO-LEGAL SERIES VOLUME 10, ISSUE 1S (2020), 10S-37S: THE FOURTH WAVE OF FEMINISM: FROM SOCIAL NETWORKING AND SELF-DETERMINATION TO SISTERHOOD

DOI LINK: HTTPS://DOI.ORG/10.35295/OSLS.IISL/0000-0000-0000-1154

RECEIVED 24 MARCH 2020, ACCEPTED 01 SEPTEMBER 2020

\section{FERNANDA MARTINS* ID}

\section{Abstract}

In this article, based on the debates of feminist criminology in Brazil, we aim to analyze feminist campaigns that use technopolitics as a strategy to face gender violence. These campaigns are exposed through the disputes between emancipatory and punitive claims. We propose to use hashtags as feminist analysis tools to understand the ambivalence present in vulnerability. In order to do so, we will use the hashtags \#ChegaDeFiuFiu, \#MeuPrimeiroAssedio, and \#MeuAmigoSecreto to analyze new meanings of justice promoted by the feminist movements, which appear not to prioritize the use of punitive power. In the same way, we seek from the \#EleNão movement, recognized as feminist democratic technopolitics, to reformulate the possibilities of analyzing the Brazilian criminological field.

\section{Key words}

Feminist criminology; technopolitics; hashtags; Brazil

\section{Resumen}

En este artículo, nos basamos en los debates de la criminología feminista en Brasil, y nos proponemos analizar campañas feministas que utilizan la tecnopolítica como estrategia para hacer frente a la violencia de género, y que quedan expuestas a través de las disputas entre las afirmaciones emancipatorias y las punitivas. Proponemos usar etiquetas (hashtags) como herramienta de análisis feminista para comprender la ambivalencia presente en la vulnerabilidad. Para conseguir ese objetivo, utilizaremos las etiquetas \#ChegaDeFiuFiu, \#MeuPrimeiroAssedio y \#MeuAmigoSecreto para analizar nuevos significados de la justicia promovidos por los movimientos feministas, que parece que no priorizan el uso del poder punitivo. Igualmente, a partir del movimiento

\footnotetext{
* Fernanda Martins, PhD in Criminal Science at PUCRS/Brazil (Av. Ipiranga, 6681 - Partenon, Porto Alegre - RS, 90619-900, Brazil) researcher at Laboratoria: espacio de investigación feminista. Email address: Fernanda.ma@gmail.com
} 
\#EleNão, reconocido como tecnopolítica democrática feminista, nos proponemos reformular las posibilidades para examinar el campo criminológico brasileño.

Palabras clave

Criminología feminista; tecnopolítica; etiquetas; Brasil 


\section{Table of contents}

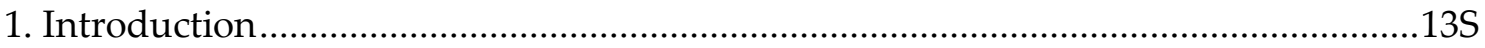

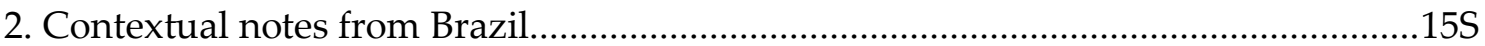

3. Technopolitics as a countersexual technology .........................................................

4. \#ChegaDeFiuFiu [\#NoMoreCatcalling] ......................................................................

5. \#MeuPrimeiroAssédio [\#MyFirstHarassment] ...........................................................

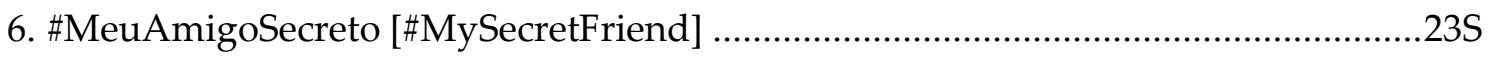

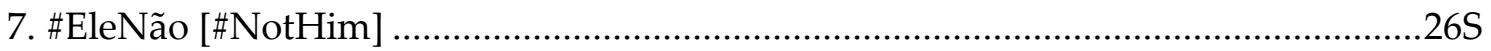

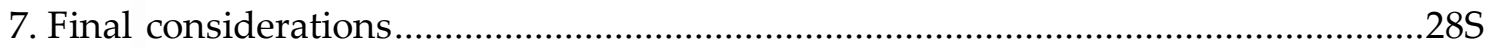

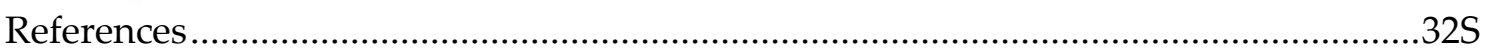




\section{Introduction}

In this article, based on the debates of feminist criminology in Brazil, we aim to analyze feminist campaigns that use technopolitics as a strategy to face gender violence.

For this, the core concept of the present analysis is based on vulnerability as a condition; as a relationship challenged by the fundamental interdependence of life with an anonymous person impossible to undo. It is an ethical bond that precedes the present and remains being updated at every moment by the forms of distribution of vulnerability. That is, there is no possibility for a life, any life, to be sustained alone. The very hypothesis of maintaining life requires a collective of multiple assumptions of subjects, material conditions, affections of unknown subjects - ethical bond - so that not only can life be lived well, but it can also remain vital. But, especially, it is assumed here that vulnerability cannot be confused with fragility or victimization, as it is not a personal attribute that can be individualized in a judicial demand or faced in a personal way, but rather a socially shared condition. At least, this is the position in which one seeks here to investigate.

In regard to feminist criminology in Brazil, it is worth noting that the investigative constructions of this field of research are particularly connected to the mainstream debates on gender violence in which the central axis of analysis is interpersonal violence, such as domestic violence and sexual violence. This limitation had the effect of creating a monolithic semantics about what feminist criminology is, whose academic productions basically revolve around the following topics: effectiveness and adequacy of criminalization as a means of tackling gender-based violence.

Therefore, here, by refusing to maintain this hegemonic sense of feminist criminology, we propose to analyze feminist technopolitical perspectives not only with one more investigative tool, but also we seek to show that the experience of hashtags works as an important analytical key to understand ambivalences that connect the debates of feminist movements and the critique of the punitive power produced by feminist criminology. This means that technofeminist research intensifies the exposure of the contradictions between the "call out" culture and the risk of falling into punitive and moralistic drifts of feminism.

The technological strategies analyzed here work as an instrument facilitating the recognition that the feminist agenda has been seeking to explain situations of victimization, without, however, excluding or reducing the capacity for agency and emancipatory policies.

To this end, we aim to carry out an analysis of the ambivalence of feminist criminology approaches, which move between punishment, organization of struggles and solidarity, leading to an analysis of vulnerability from a transfeminist perspective. ${ }^{1}$ In this sense, it is clear that the present ambivalence between the demands for emancipatory rights and the limits of punitive power is expanded when the hashtags are incorporated as political instruments connecting demands and claims. It is noticed that this experience connects to technopolitics as practices that expand the spaces and the voices that produce politics

${ }^{1}$ We use "transfeminist" to express that the feminist analysis used to interpret the object of this article is shared by the plurality of global experiences and the multiplicity of gendered bodies. On the subject, see Sayak 2010. 
in traditionally constituted social movements, while also producing inventive ways of doing politics.

Therefore, the questions that guide this reflection seek to understand: a) How do these connections and ambivalences affect feminist criminology, but, in particular, how do these ambivalences affect subjects in criminology, as subjects of violence, activists and researchers? b) How are digital tools being used as strategic elements against gender violence? c) How is "'hashtag activism' responsible for building bonds among women, creating networks of mutual support and strengthening their awareness of social and legal rights"? (Peroni and Rodak 2018).

Initially, we propose to work with two research fronts about the issues mentioned here. The first is to identify how new technologies, especially social media, are promoting a transnational confrontation through the feminist tools of analysis to understand the phenomena of localized violence. To do so, the hashtags \#ChegaDeFiuFiu [\#NoMoreCatcalling], \#MeuPrimeiroAssedio [\#MyFirstHarassment] and \#MeuAmigoSecreto [\#MySecretFriend], are used to analyze new senses of justice promoted by feminist movements, which apparently do not prioritize the use of punitive power.

These hashtags were selected as an object of analysis because of the wide-ranging repercussions that resulted from them in Brazil. The first promoted debates that, connected to the second movement, translated punitive demands in the criminalization of the conduct of "sexual harassment", at the same time that they were intimately connected to the creation and promotion of tools that help women in case of violence. These two hashtags also made it possible to produce cartographies and audiovisual resources that generated collective campaigns to confront harassment practices in public spaces, such as buses, subways and workspaces. The \#MeuAmigoSecreto [\#MySecretFriend], by presenting a narrative different from the previous ones, produced a wide range of activities and exposed, in a more specific way, how diversely violence is crossed by the various vulnerabilities that expose lives to different forms and intensities of aggression, such as racism, economic inequalities and territorial disposition. These three technopolitical movements are closely connected to the manifestations promoted by Brazilian women in October 2015, known as "feminist spring".

It is important to note that unlike the \#MeToo movement, ${ }^{2}$ neither \#MeuPrimeiroAssédio [\#MyFirstHarassment] nor \#ChegaDeFiuFiu [\#NoMoreCatcalling] proposed individualized complaints against the "authors". The proposals, despite the language deeply connected to the criminal semantics, did not aim to identify the subjects who carried out the actions, but tried to construct a collective conscience of the victim's perspective. Despite the victim's position maintaining a punitive structure, it is undeniable that the two hashtags intended to horizontalize knowledge about naturalized gender-based violence.

The second proposal is to identify if there is a certain punitive rationality in the exposure of violence through social media, and in what way it is possible to extend the reading of these instruments as mechanisms of new political propositions. In this sense, we invest

\footnotetext{
2 On the connection between the \#MeToo movement and Brazilian feminist movements, see Jarrin and Caldwell 2018.
} 
in an attempt to understand \#EleNão [\#NotHim], a Brazilian movement developed as a feminist democratic technopolitic articulation to reformulate the desires of new possible worlds. In this sense, despite the fact that \#EleNão was constituted from an apparent rejection of a candidate in the electoral period, the articulation proposal sought to confront the naturalized representation of white masculinity promoted by Jair Bolsonaro. Declarations and violence perpetrated by the then candidate were seen by various social groups, especially feminists, Lesbian, Gay, Bisexual, Pansexual, Transgender, Genderqueer, Queer, Intersexed, Agender, Asexual, and Ally community (LGBTQIA+) and Afro-indigenous people, as a setback to social and political conquests, disrespect for minimum democratic guarantees and an explicit danger to human rights defenders (Uchoa 2018). Therefore, inserting \#EleNão as a possibility to understand how techno-feminist articulations have been developing new forms of political intervention is a strategy to analyze the current resistance in Brazil to the misogynist, racist and conservative speeches represented by the country's now president.

\section{Contextual notes from Brazil}

In Brazil, the debates about gender violence that cross the criminological studies are built especially on the ground of a reactive production to the processes of criminalization of domestic violence and sexual violence against women, directed at interpersonal relations.

From the self-proclaimed feminist criminology knowledge, a movement to construct critical criminology concerned with gender violence, developed in the Brazilian discussions on the strategic inclusion of feminist theories in criminology research, this translates into a meeting of low intensity in terms of entrenching a gendered perspective in critical criminology. Critical production seen as the result of contamination by problematic "extra-legal" feminist theories is generally reduced to legal/penal issues. A kind of simplifying translation of the complexities of gender knowledge, consubstantially captured by the discussion of criminal strategy as legitimate against "gender violence", reduced to the identity "woman" - not necessarily linked to the biological meanings of the expression, but connected to the position of "victim".

The term "feminist criminology" can also be considered to have risen from within the criminological knowledge traditionally operated in the sphere of punitive power. Hence the concern, in general, only with criticisms of legislative policies or with the judicial operation of violence against women (Campos 1998, 2003, 2015, Debert et al. 2006, Celmer 2008, Alimena 2010, Mendes 2014, Montenegro 2015, Souza 2016, Castilho 2016). In other words, the feminist perspective in criminology was limited to criticizing technical and legal aspects of criminal procedures for gender-based violence as secondary victimization, and in the debate on the effectiveness of punitive power as an instrument of protection.

This finding even allows us to understand why the "feminist criminology" debate in Brazil has remained almost hegemonic on violence against women, restricted to domestic and sexual violence, since its emergence has occurred based on new criminal 
proposals. $^{3}$ This meaning of feminist practices based on the criminological object of gender violence is profoundly representative of the works produced until recently, which, in short, materialize in the figures of the woman victim or author.

Indeed, this "feminist criminology" movement, as a reaction to the processes of criminalizing legislative policies, also allows us to understand why feminist debates about female imprisonment have recently become a more urgent concern. Although is does not occupy a "highlighted" position within the reflections of Brazilian feminist criminology, maintaining itself as an autonomous expression ("incarcerated women"), this dialogue has increased as the rate of female imprisonment has broadened by $670 \%$ (Santos 2017) in the last 13 years. This is an implication of the Brazilian drug policy and traversed by the genocidal policy of the Brazilian State forged on a misogynist racism (Reis 2019). ${ }^{4}$

The processes of criminalization and imprisonment of women, mostly black women, deriving from the Act 11343 of $2006,{ }^{5}$ projected a need for a reanalysis of the criminological discourses contaminated by feminist theories. When facing the acute effects of prison on the bodies of imprisoned women, and in the systematization of the lives of the women affected by imprisonment (Alves 2017), which became responsible for maintaining the prison system (Godoi 2016, Borges 2017), it needs to be considered that the Brazilian prison system was expanded after the exponential increase in prisons linked to drug policies in the country. The discussions established on "women and prison" are the ones that have contributed most substantially to the widening and qualification of gender debates, consisting of criminological production that involves discussions of race.

In this subject, the most recent investigations about the imprisonment and the interrogations of the criminal justice system's racist functioning, which were based on a proposal for the production of openly militant knowledge and produced on an "intersectional" perspective (Crenshaw 1991), point to the urgency of widening the perceptions and concerns of criminological knowledge. This considers the radical imbrication between domestic violence against women and state and structural violence, intersected by raciality and its nuances of the neoliberal order. Issues of racism, labor

\footnotetext{
${ }^{3}$ In addition, we can say that the progress of the so-called "queer criminology" also goes through the debates of criminalization that cross the practices of prejudice against LGBTQIA+ groups. This is another semantics agglutinating to criminology as a reactive debate to the processes of criminalization or discussions crossed by the legislative criminal sphere.

"Unlike the long trajectory of "feminist criminology" produced in other countries, such as the USA, the debates on the imprisonment of women, racism as an intersectional issue in the processes of gender violence and the unequal distribution of exposure to violence (Davis 1997, 2017, The Critical Resistance-Incite! 2008, Stanley and Smith 2011, Alexander 2017), in Brazil they assume autonomous research fields that are not necessarily linked to what is referred to as "Brazilian feminist criminology". It is not ignored that within the feminist criminological field there has always been research committed to think about these connections, however, the field entitled "feminist criminology" has started to introject this semantic more abruptly in recent years, especially from a criticism produced since the perspectives of black feminism and the antiracist struggle against mass incarceration (Flauzina 2008, 2016, Alves 2017, Borges 2017).

5 The Maria da Penha's Law (Act 11343 of 2006) is a Brazilian federal law, the main purpose of which is to punish "effectively" and to prevent acts of domestic violence against women. The law came into force on September 22, 2006 and was formulated by a consortium of activists and feminist organizations, after Brazil was condemned by the Inter-American Court of Human Rights, for failing to make a proper judgment in the case of the attempted murder of Maria da Penha.
} 
relations, economic precarization, the feminization of poverty, militarized interventions in the favelas, gentrification processes, projects for access to popular housing, etc. are not often present in the discussion of this so-called Brazilian feminist criminology.

This element of reconfiguration of the feminist researches and struggles, closer to the knowledge of critical and feminist criminology, was marked by the new policies of access to Brazilian universities (Batista Jr. 2019) in the early 2000s. The quota policies for public universities introduced by the PT governments ${ }^{6}$ were not only substantially important, but the policies of credit facilitation, promoted by state capitalism (Safatle 2017, Amaral 2018), also marked this period and accelerated the entry of new social groups into private institutions of higher education. This expansion of access to higher education institutions allowed the pluralization of hegemonic and homogeneous spaces, public or private, which until then had established themselves as a breeding ground of privileges, feeding their productions as to maintain their domain in the production of knowledge (Foucault 1996).

In this sense, these inclusion policies were radically responsible for expanding the political debates in academia, positioned as a path of knowledge forged on an "activist" nuance, whose recognition of inequalities and unequal distribution of opportunities in Brazil became the central element of analysis from other previously invisible perspectives. These contours impact the scene of critiques confronting a production of academic knowledge until then established "on the other" (Spivak 1997, Carneiro 2005, Flauzina 2008), shifting to the construction of political knowledge produced "by us and for us" (hooks 2000).

The centrality of social realities, stemming from an interlocution with social movements - organized and/or autonomous -, in academic productions, has revealed a dramatic fissure in the main questions of research and teaching. It is through these new readjustments that the approximation of gender violence and punitive power will be taken by new possibilities of analysis.

Among these elements of economic redistribution we find another important aspect for the production of new questions and challenges to the feminist movements and their consequent reflection. Internet access, especially through cell phones (Meirelles 2018), and the possibility of acquiring electronic devices with the use of facilitated credit brought new forms of knowledge production and disputes over political discourses that before were kept in designated spaces by the artificial neutrality that produced knowledge in universities and politics in the streets.

Here, we do not intend to expand, or even to enumerate, all the contours that fomented the insurrection that has occurred in the last years in Brazil. The issues brought in this paper are symbolic knots of a material readjustment that allows this current analysis of the fourth wave of feminism that propelled a debate on strategies to confront gender violence in Brazil through the "hashtag feminism".

${ }^{6}$ Brazilian Workers' Party. 


\section{Technopolitics as a countersexual technology}

Stemming from the lines already outlined by many feminists, the urgency to use diverse instruments to research questions that involve gender performativity is a call to reposition the questions and, consequently, possibilities of answers other than those already established.

If vulnerability is to be "exposed to language before any possibility of forming or formulating a discursive act" (Butler 1990), here feminism is being understood, at least in part, as "a political term, a questioning of power and of the possibility of change, and not only [as] a question of technique" (Shiach 1989, p. 205), to instrumentalize the technological senses now arranged through social networks to interrogate the accessible language processes is a strategy for confronting the hierarchies.

The aim is to abandon the victimizing position implied in the punitive strategies applied to women in situations of vulnerability. Therefore, disputing the meanings of language that expose them to the innumerable meanings of violence involves formulating political terms crossed by the usual use of technologies as a tool of emancipatory claim, even within feminist movements themselves.

It is in this context that we understand that talking with and through the feminist debate always becomes a process of "displacement" (suffered by agents throughout history) or of "subversive resistance" (Butler 1990) to conceptions/roles/attributions of women in the construction of society as a possibility of new paths.

Therefore, to think of narratives from what is more substantial, bodies (not docile), touched by the history of those we cannot even name to the ones that we cannot even predict, is to reconstruct the possibility of recognizing all lives as lives worth living (Butler 2015a). It is to take away the consciousness of exclusion (Haraway 2002, p. 232) present in the binary thought arranged by the virtual or real, approaching distances and diverse realities through a shared embryo that are the transfeminist practices also forged inorganically with the use of technology, but always produced by meetings of bodies.

In this cyborg fusion in which writing and speech are subversive tools that allow us to survive, the "cyborg world may have to do with real social and bodily realities, a world where people are not afraid neither of their affinity and connection with animals and machines, of their permanently partial identity, nor the contradictory positions" (Haraway 2002, p. 231).

Collective mobilization that follows social media and creates movements of bodies in alliance also goes through the emotional sense. If, in times of conservative and neofundamentalist advances, the position taken by these groups has been reinvigorated and intensified by the manipulation of emotions, especially of collective resentments (Brum 2019), ${ }^{7}$ the struggle to understand cyberspace and to use it as a resonance of complicity, autonomy and political strengthening of feminist solidarity, is a pressing commitment of the moment (Comité Invisible 2017). Therefore, betting on this strategy as a circuit of

\footnotetext{
${ }^{7}$ Brazilian elections were largely touched by the discursive disputes of social networks, especially through Whatsapp and Facebook. Not only the Brazilian case, but the US election and the Brexit case in the United Kingdom point to the new strategies of governmentality that determine the political destinies implied in the neoliberal logics.
} 
affections (Safatle 2015) to understand the punitive power, is a question of investigating whether the processes of commotion generated by hashtags linked to the feminist strategies are accompanied by the consciousness of the plurality of this space and of an agenda of resistance against criminal intervention by the State and its apparent reasons.

It is in this sense that the reactive responses to the processes of criminalization operate in a contour of impoverishment of the possibilities of creation. Reactivity is always directed by strategies that order bodies and lives. Therefore, reallocating the debate on vulnerabilities forced by the unequal distribution of political force as an ethical compass is the way to seek new destinations to pursue.

The displacement of language around the "gender troubles" (Butler 1990) and the "criminal issue" (Zaffaroni 2013) also poses as inseparable to redefine meaning to resistances. To use the category "gender" as "counter-technology", that is, as a bet on the production of other forms of resistance ungovernable by punitive power through shared strategies that invest in "democracy to come" of "bodies in alliance" (Butler 2017) is a radical task.

The position here is to seek "a transfeminism that allows us to think beyond the limits of our options, that is to say, in a determined and oppressive context, we must create theoretical and practical tools to help us draw up strategies (...)". In conclusion, "if there is no other option, let it not kill us, but by means of our daily insurrection re-signify us" (Sayak 2010, pp. 11-12).

This proposal, through this gap, seeks to think of alliance strategies that reformulate the meanings of "justice", such as those proposed by collectives such as Ni Una Menos [Not one less], the hashtags produced locally and globally by feminist movements pointing out new directions to denounce situations of extreme vulnerability.

\section{4. \#ChegaDeFiuFiu [\#NoMoreCatcalling]}

According to the webpage of the organization, the "No More Catcalling" proposal was "a campaign to combat sexual harassment in public spaces", which initially published "illustrations with messages repudiating this type of violence". The images reached thousands of people on social media platforms (Think Olga 2018). In continuity, due to the impact that it generated, the "journalist Karin Hueck has launched an online study, through the website Think Olga, to ascertain closely the opinion of women in relation to catcalling". 8

The result, after two weeks and with "almost 8 thousand participants", revealed that " $98 \%$ of women who answered the survey had suffered harassment before, $83 \%$ did not think it was acceptable, $90 \%$ had changed their clothes before leaving home thinking on their way because of harassment before and $81 \%$ had stopped doing something (going somewhere, walking in front of a construction site, going out on foot) for the same reason".

\footnotetext{
${ }^{8}$ Think Olga is a think tank that discusses feminist issues, which identifies itself as "a feminist NGO created in 2013, with the goal of empowering women through information. The project is a content hub that addresses topics important to the female audience in an accessible manner" (https://www.thinkolga.com/).
} 
The questionnaire (available at http://chegadefiufiu.com.br/) begins by asking: "Where have you heard a pick-up line?" and then establishes the word "harassment" as a natural synonym for the expression "pick-up line", both expressions are used throughout the questionnaire without any specific treatment that modifies or differentiates their meanings.

Among the developments following the campaign, a project entitled "No More Catcalling Map" (http://chegadefiufiu.com.br/) was developed, which is identified by the organization as "a tool to make cities safer for women by geographically relating the locations and motives that increase the incidence of harassment in certain areas in search of solutions to change that reality". The app presents a map of Brazil with three options. The first is to search for the name of a city, check the regions of experiences reported and view the reports presented through the location tag. The reports are usually anonymous, pointing only to the local and time. Another option is to share your own story on the page - Share your story -, and the last is to make a complaint about "what have you seen", that is, to report a situation that the user has witnessed but did not suffer him or herself - Denounce what you have seen.

Tools 2 and 3 have gaps to fill in "type of harassment" - with options provided by the page itself -, date, period of the day, income, schooling, age, color, name, email, description and an option to publish the information anonymously. It should be noted that the elements provided by the website to submit online testimonials have a similar criteria for submission as filing a Police Report in the case of reporting to police agencies, except that there is the possibility of maintaining anonymity or choosing the option $I$ prefer not to say, available on some of the items.

The other result of the campaign was a documentary feature film inspired by the research carried out by Think Olga with the same name, released in May 2018. For directors Amanda Kamanchek Lemos and Fernanda Frazão, the question that drives the production is: "Have cities been made for women?".

The film's top priority is to "explain the types of harassment and how the law sees these crimes", arguing that "the idea is to get women to understand what the legal devices are. Because if you arrive today (05/2018) in a police station and say that you have been harassed, in fact, you have little support. It is important to know the law". In addition, they said that "the film serves to poke at people. It is not only made to explain reality. It is also done to poke at the thoughts, to reflect, to question the truths that are put" (Martinelli 2018).

These three projects linked to the same campaign share the punitive reading implied in women's "safety" demands. Furthermore, the narratives of all these experiences go through a requirement of 1) characterization of "criminal" behavior, reverberated through expressions such as "complaint", 2) leveling of the terms "pick-up line" and "harassment", 3) knowing the criminal "law", 4) combating underreporting of occurrences to the criminal justice system and 5) enabling victims to understand that they are not alone and that what occurs is not only with them.

What is important in order to understand this language and the demands of punishment implied in it is that, by the end of 2018, the behavior "harassment" was not criminally predicted under such semantics. However, through recent movements demanding 
specific criminalization, the crime of sexual harassment was included in criminal legislation after the amendment of the Criminal Code (Act 13718, dated September 24, 2018), which accounted for the conduct of "disclosure of rape scene or rape scene of vulnerable person, sex scene or pornography", and the causes of increased sentence in cases of "collective rape" and "corrective rape".

This amendment also modified the way in which the prosecution was instituted by the responsible authorities. Until then, in cases of "crimes against sexual freedom", the victim should represent against the perpetrator, that is, the manifested intention of the victim to sue the perpetrator was indispensable. However, since the mentioned modification, the criminal procedure must be initiated even without express desire of the victim and its continuation should be carried out even when the victim does not want to follow its unfolding.

In this sense, the "No More Catcalling" experiment was one of several technological tools to have developed with great intensity since the year of 2013 in Brazil. However, the choice to indicate it as a "precursor" was taken because the width of work carried out by Think Olga came in several forms, which caused a significant online repercussion through the hashtag and the map. But not only did the impact take place digitally, the documentary produced from it was broadly broadcasted in universities, schools and public spaces. In this sense, the debate about harassment as a mechanism to "know the law" and to "recognize oneself in the situation of the victim" has obtained immense profusion in diverse perspectives of the Brazilian reality. Moreover, the creation of the "sexual importuning" law, specifically focuses on a response to "harassment" in public places, in direct dialogue with the claim proposed by the movement analyzed. ${ }^{9}$

\section{5. \#MeuPrimeiroAssédio [\#MyFirstHarassment]}

At the end of the second half of 2015 the Brazilian streets were taken by several feminist movements, which led to this period being known as "feminist spring". These mobilizations were orchestrated on the basis of several factors that crossed legislative policies, elements of the great national media and an articulation engaged through social media platforms.

Among the episodes that mobilized the uprisings at the time, the hashtag \#MeuPrimeiroAssedio [\#MyFirstHarassment] was one of the developments whose importance was closely linked to the political actions of that context. The launch of the hashtag was also proposed by the collective Think Olga after numerous comments were

\footnotetext{
${ }^{9}$ In 2017 in the city of São Paulo there was a case that was widely debated through social networks and became a factor that impelled the demands of punishment of the crime of "sexual harassment", in which the focus was the protection of women in public spaces. A man ejaculated on a woman's neck on public transport and was released immediately because there was no "legal" framework that could keep him in jail, and especially the criminal type at that time required "violence or grave threat". Also, the Brazilian male criminal law theory understood that the man's masturbation on public transportation was not "a grave threat". This episode was extremely relevant to boost the claims of punishment. However, the new criminal law that began to typify conduct of this order was not received completely with joy in all feminist movements. In particular, researchers who have focused on gender issues in punishment strategies - not necessarily within the perspective of "feminist criminology" - have denounced that criminal law was an effective mechanism and a response that weakens the claims of policies to combat gender based violence (Prando 2017).
} 
made on Twitter about a 12-year-old girl who participated in the television reality show MasterChef Junior. ${ }^{10}$ After the debut of the television show, this participant became a subject in social media platforms, where posts mentioned her beauty, her body and especially her sexuality.

This episode raised some discussions, and two especially were articulated with digital action. The first one was on pedophilia, where the discussion focused on child abuse and naturalized harassment attacks. The second was directly connected to the first issue, about the looks directed to the bodies and sexuality of girls and teenagers.

One of the comments that circulated on the platform and raised this debate was the question: "If there is consent, is it pedophilia?" This interrogation, among other statements, leveraged a collective process of backlash, especially for the natural way the question was proposed in an open space such as Twitter, thus showing the shadows of normality that are available on everyday life outside social media. Not only the content, but also the amount of other posts that followed the same tone generated indignation, by widening an open wound to which girls, adolescents and women are exposed in Brazil - the "harassment", but, particularly exacerbated by the practices of violence throughout childhood.

The movement "Meu Primeiro Assédio" [My First Harassment], therefore, encouraged women to reminisce and report, through social media, what was their earliest memory of harassment, moral or sexual, involving their status as a woman. According to the NGO, women were "invited to share their stories (...)", even though they understood that it would not be a "simple, painless, easy mission", but affirmed that taking over the story itself would be important, so that the victim should recognize themselves as a victim (PV Mulher 2015, Think Olga 2015).

The results presented were based on a collection of 82 thousand hashtags shared only through twitter, which analyzed a group of 3,111 stories, pointing out that "the average age of the first harassment is 9.7 years - and most of the crimes, $65 \%$, are committed by people known by the victim" (PV Mulher 2015, Think Olga 2015).

The NGO's page, when publishing the details about the campaign, reported on the personal experience of Juliana de Faria, the founder of the organization, as the reason for the engagement, and described that the silence about experiences of abuse is marked by chauvinism, in which this process generates guilt victims and cover-ups of men. It also exposed that "hiding" or denying the issue socially works to "keep the victims silent" and that this provokes reactions to any complaints, considering them "an exaggeration" or "victimhood". Therefore, "discovering oneself as a victim", according to the webpage, when taking control of one's own story is "very powerful", because when confronting it publicly the "victims" "begin to let go of the gags: they understand that what happened is wrong, that the support that they did not receive or were afraid to seek at the time is also a result of chauvinism, as well as any notion that they had provoked or allowed the fact to happen. At last, they discover themselves victims of sexual harassment, even in childhood. And, finally, they can see clearly that there is a culprit, and that it is not them".

${ }^{10}$ Children's edition of the culinary reality show MasterChef. 
The justification speech that backs the hashtag is highly woven by penal language. Such characteristic establishes that the punitive discourse involved the proposal as a matrix of articulation. However, reporting oneself (Butler 2015b) is always a process of reappropriation of life, of other narratives, diverting their own gaze from the remains of their past, as a force for new trajectories. The experience of reporting oneself is inescapable and moves fate from the shifts that one makes. This ungovernable movement also leans in punitive strategies, materialized by state agencies in Brazil in the case of the claims of criminalization of harassment.

The initiatives of the so called "fourth feminist wave" that appropriate technologies as a mechanism of solidarity and construction of feminist struggle are invariably actions that relate to each other, and that reconfigure meaning to the previous initiatives themselves. Therefore, we cannot deny that the rationality of punishment was established between the debates proposed, but with new strategies, new languages and new ways of relating violence with more plural mechanisms, the demands connected to the criminalization processes are no longer a priority as we can see through the \#MeuAmigoSecreto [\#MySecretFriend] action.

\section{6. \#MeuAmigoSecreto [\#MySecretFriend]}

The Twitter hashtag \#MeuAmigoSecreto [\#MySecretFriend] was another social media movement deeply touched by the context sharing narratives with the people occupying the streets during the "feminist spring" in Brazil.

The spontaneous digital movement apparently started through the online feminist community Não me Kahlo (Padrão 2015). The action took place as an ironic approximation to a typical Brazilian holiday game, when family and friends get together to exchange gifts, give tips on the person's characteristics so that others discover who will receive the present.

In a quite different way from the technological action promoted by \#MeuPrimeiroAssédio [\#MyFirstHarassment], \#MeuAmigoSecreto [\#MySecretFriend] revealed a series of short testimonials about naturalistic oppressive behaviors, or rather, hypocrisies, exposing the daily life of women in their interpersonal relationships through practices that are radically present in the day-to-day circuits. It was not a question of pointing at behaviors that would be closely related to materialities recognized as violent, capable of any criminal debate, but to identify a series of incoherent behaviors practiced among people of their coexistence, which are often not recognized in the local of hierarchy and of reproduction of systematic violence produced by racial, sexual, and other prejudices.

According to an online portal, the first postings were unfolded from the following comment: "My secret friend says that abortion is murder but he asked his girlfriend to abort when she became pregnant" (Padrão 2015). As a hashtag, the same portal indicates the following precursor tweet: "My secret friend says he is not sexist but he finds my posts talking about feminism annoying. \#MeuAmigoSecreto" [\#MySecretFriend].

That was the tone among the comments. The friend's name was not exposed, neither was the relationship between the people involved or any other detail that led to identifying the subject. The idea was to point out the innumerable contradictions present 
in the lives of women, especially about the freedom of their bodies, their sexuality and their political and professional positions.

In particular, one of the readings that can be made of this movement is that the contours of exposure revealed so many contaminations of the structures that forge the subjectivities in Brazil that anyone could recognize themselves in the posts of any other.

This experience had a very ostensible reaction of criticism, founded by stating that the social media platforms were being used to "denounce" people through the "Internet Tribunal". Quite different from the responses to \#MeuPrimeiroAssedio [\#MyFirstHarassment], which were positive among the majority of the left and maleproduced media, \#MeuAmigoSecreto [\#MySecretFriend] caused widespread discomfort.

A Brazilian writer by his comments on the subject demonstrated in a very synthetic way how the debate against this movement took place: "\#PrimeiroAssédio was fundamental. \#AgoraÉQueSãoElas [\#NowIt'sThem] ${ }^{11}$ was beautiful. Now, this \#MeuAmigoSecreto... If you have a serious accusation, Maria da Penha is there for you. If you have a less serious accusation, go there and fight with the guy. But keeping this veiled delation, in this climate of 'Car Wash will get you and you know it is you I am talking about...' ${ }^{\prime 2}$ Kind of weird, is it not?" (Prata 2015).

Other arguments that "thickened" the critique of the movement indicated that the hashtag would have a tone of gossip or escracho. As any political proposal articulated through cyberspace produces its own dimension and sense, of course, the limits of the articulation were not ignored. But it was able to express, in a different way to the configurations of a crime practice, the traces of incoherence as a very sandy terrain to the subjectivities crossed by the stories.

In this sense, the victim's position in a context of "virtual exhibition" produces comfort to the symbolic constitution of the criminal, another in which the tactics of punitive power are implicated in a neoliberal society. The demand for individual responsibility by resorting to the judiciary - or "fighting with the guy" - is an effect of narratives that understand that responsibility for the problems of violence lies exclusively with the specific perpetrator, as if there was nothing beyond the capture of a duly identified and identifiable subject.

The punitive or even legal response fuels the idea that gender-based violence refers to exceptional, criminally foreseen "conducts" that allow the detection of "perpetrators", always with behaviors that are never close to "normality", to daily practices, to contexts shared by common experiences. In this sense, "the legal device encapsulates normative categories - violence, homicide, femicide - social facts" (Arduino 2018, p. 55), through the punitive strategy that reinforces the relations of separation. This dichotomous production between those who are violent subjects and all the others reaffirms the sentence as a measure applied to the enemy of the time.

11 The movement \#AgoraÉQueSãoElas was an initiative in which several men gave space in their columns of large-scale newspapers and online portals to feminist activist women to talk about their struggles.

${ }^{12}$ Reference to the delations produced in the legal operation entitled "Lava Jato" [Car Wash Operation] that led to the arrest of former President Lula. 
The collective interpretation captured by the criminal language indicates a stable location to the unfolding of collective actions, which reinforces the naturalness of the practices that are not assimilable by such semantics. It is noteworthy that the selective reinforcements of punishment produce a shared logic that imprison only "barbarism" and that "in prison, only psychopaths are identified, serial rapists who mutilate pussies with glass shards or pedophiles attacking young girls. Because they condemn rape. But what they practice, that is something different, always" (Despentes 2016, p. 30). ${ }^{13}$

Still on the meaning of the "victim", the passivity that configures the status and the unfolding of punitive actions that generate comfortable views, we perceive that the criticism that points out the aggressiveness of the escrachos ${ }^{14}$ generates a displacement on the subjects involved in the spheres of annunciation. The stereotype of aggressiveness (Collins 2016, p. 104), which involves the reactions promoted by resisting situations of violence, is also a fundamental device of the naturalized hierarchies. Therefore, the impotence and silence of those who are positioned as victims, the pain transferred to the revenge discourse orchestrated by the penal perspective - instrumented by the state reinforcement, is subjectively distorted when an ironic strategy is produced by unmasking the most invisible details arranged between us and destabilizing expectations about subalternity.

This strategy for recognition (Fraser 2000) is not necessarily by rights, but by what is arranged in the human relations of everyday practices. It is a common contour that is present in the movements of the hashtags discussed here. However, the limitation of discourses involving criminal legal semantics, here thought of in the claim to be called "victim", cannot ignore the unequal distribution that is attributed to that expression.

If the contribution of intersectionality really involves understanding that race, gender, and class contaminate exposure to vulnerability (Davis 2016), claiming that language is to contribute to the most deadly system of vulnerable groups we have, the penal system, reinforced by demands of emancipation, deeply captured by a narrative of renunciation of their own assemblages, as if they were disposable or non-existent in the position of the subaltern (Spivak 2010).

SexPolitics is, according to Preciado, "one of the dominant forms of biopolitical action in contemporary capitalism. With it, sex (the so-called "sexual" organs, sexual practices and also the codes of masculinity and femininity, normal and deviant sexual identities) enters into the calculation of power, making discourses on sex and normalization technologies of sexual identities agents of control of life" (Preciado 2011, p. 11). This implies understanding that if to some extent biopolitics is the governing of bodies, disposing of life and death (Foucault 1996) and about which lives are killable lives and which are lives worthy of being lived (Butler 2015a), the very definition of victim is a sexpolitical strategy for the production of identities by power relations, reduced to fixed

\footnotetext{
${ }^{13}$ On the imprisonment of barbarism, the black feminist movement operates as a theoretical foundation for understanding the racist dispositions that involve the criminal justice system.

${ }^{14}$ Escracho is the term used for a certain type of public demonstration in which activists are concentrated in front of workplace or residence of a person who aims to publicly denounce. The escracho can acquire an intimidating or persecutory character, when it includes the use of more or less violent tactics. In a more contemporary way, escracho has been carried out through social media to indicate dissatisfaction and disapproval of the conduct of people, groups, organizations, political positions.
} 
and reductionist categories, through which gender has the potential to subvert at any moment.

In this sense, in spite of the political reality that involves the tactics of affirmation of rights, a strategy that feminism cannot give up, the questions are directed to understand which negotiations are being carried out with the punitive neoliberalism that is constantly revealed as a mark of colonial extermination of vulnerable women and groups, that is, of the precariousness signaled by the SexPolitics that directs the calculation of power.

These developments, however, acknowledging the problems involved, were essential to the feminist uprising that occupied the streets of Brazil in 2015. The manifestation that occurred at the end of that year against a Bill (PL 5069/2013) aiming to prohibit the use of the morning-after pill and to hinder access to abortion by women who got pregnant as a result of rape, was intensified by digital narrative disputes.

According to historian Margaret Rago, feminist movements have profoundly transformed

culture and public life in Brazil, by struggles that are directed towards very diverse fronts, in politics, in religion, and especially in thought. Fighting violence against women means, in our view, not only to face situations such as rape, domestic violence, deprivation, humiliation and physical exclusion of women, but also face them in the symbolic and social imaginary, transforming misogynistic and sexist ways of thinking that rank the world and produce authoritarian and excluding regimes of truth. It means dissolving the male, universalist and binary historical narratives (...). (Rago 2014)

This transformation has not only heightened feminist debates in recent years, but also, through the very understanding of limitation and the challenges that surround them, has produced new experiences marked by the shared desire to refuse what is available as reality. Radical resistance as an excess to the patriarchal/capitalist intervention that forces a "sealed identity closed in on itself", a trans-position that puts in check the predetermined symbolic register (Maia 2019). An evident example of this type of proposal in Brazil is the \#EleNão [\#NotHim] movement.

\section{7. \#EleNão [\#NotHim]}

New experiences, therefore, are being produced concomitantly among all possible spaces of dispute. Not only institutionally, feminist movements have broadened the debates about violence, rights, work, precariousness, taking the conception of politics and public space for themselves, without ruling out the implications of the domestic relations that produce the very sense of public.

Among these movements of insurgencies articulated between bodies and technology, the movement \#EleNão [\#NotHim] can be taken by innumerable analyzes and readings of its unfoldings. However, what we propose to explore here is established in the horizontal and plural strategy that movements articulated by networks of solidarity, fundamentally established through feminist readings, such as \#NiUnaMenos [\#NotOneLess], are taking a central position in political practices.

In the Brazilian case, the promotion of hashtag \#EleNão [\#NotHim] came from the creation of a Facebook page, founded by Ludimilla Teixeira - a black woman from the 
Northeast of Brazil - titled Women United Against Bolsonaro (MUCB). This group gathered, in just a few days, 4 million women, putting in contact unknown women and women coming from all over the extensive Brazilian territory, united by the rejection to the then candidacy of Jair Bolsonaro. The group's main concern was, in addition to promoting local actions, to find women who shared the desire to discuss and act on the candidate's election and his open misogynist pronouncements.

The Brazilian electoral process in 2018, especially the presidential one, openly expressed characteristics of the androcentric politics of the institutional government strata. Not only due to the pronouncements, but also due to the political proposals that unfolded from the candidacies, women's discontentment with the options presented by the political scenario became explicit. ${ }^{15}$

When asked about the group's widespread adherence, the founder, Ludimilla Teixeira, said she sensed that it had happened because of the very many chauvinist comments made by Bolsonaro, not only during the electoral process, but also in earlier moments, ${ }^{16}$ "as when he told federal representative Maria do Rosário that he would not rape her because she did not deserve it". ${ }^{17}$ Other manifestations of explicit violence pronounced by the current president of Brazil are part of a long list, but one that had profound repercussions was the assertion that women should receive lower wages than men, because they can get pregnant.

These elements constituted the portrait of the elections in Brazil, in which 52\% of the 147 million voters were women and the rejection rate among them to the candidate, according to the Datafolha poll of September 11, 2018, was that $49 \%$ affirmed that they would not vote for him at all. This portrait profoundly damaged interpersonal and affective relationships for a significant part of Brazilian society.

Stemming from these contours, \#EleNão [\#NotHim] promoted the mobilizations that took place on September 29, 2018, in Brazil and the world. There was no official data collection on the number of cities and participants involved, but estimates indicate that the mobilization brought together more than 1 million demonstrators in hundreds of cities in the 26 Brazilian states, where women's protagonism became evident and became a priority. Among the national figures raised, we can point out that "the highest numbers were recorded in Cinelândia, Rio de Janeiro, where more than 200 thousand people protested, and in Largo da Batata, in São Paulo, where another 150 thousand were together". ${ }^{18}$ In the international spectrum, mobilizations against Bolsonaro were reported in 15 cities in 10 countries, including Germany, Portugal, Argentina, Australia, Canada, Spain, France, the Netherlands, England and the United States.

Although the demonstrations did not prevent the current president from being elected, the scenario posed by Brazilian women had a significant impact on the national politicalsocial context and even on feminist re-analyzes. This episode cannot only be considered a historical moment in which feminism and the struggles for the rights of women have

\footnotetext{
${ }^{15}$ On the figure of Bolsonaro, his election, the impacts of masculinity on national policies and the dismantling of social policies to vulnerable groups, check Brum 2019.

16 Jair Bolsonaro has been in the national political scenario for 27 years. To understand his trajectory, check Potter 2018.

${ }_{17}$ About the manifestations of \#EleNão [\#NotHim] in Brazil, check Brunelli 2018.

${ }^{18}$ About the manifestations of \#EleNão [\#NotHim] in Brazil, check Portal Catarinas 2018.
} 
been placed as a sign materialized by political bodies in alliances (Butler 2017), mobilizing people, affections and movement on the streets, but it can also be recognized as an exposed nerve of the plural demands that produce re-significations to democracy and feminist debates themselves.

It is important to point out that the movement \#EleNão [\#NotHim], despite having been raised and carried out by women, reveals the objective substratum of what transfeminist policies (Sayak 2010) mean, since it took as main agenda the rejection of the candidate and of everything that he and his priorities of governments represented. This means not only a desire to say "enough" to the reality of violence against women, but also against LGBTQIA+ groups, indigenous peoples, black people and all other bodies that are marked by the vulnerability of precarious lives (Butler 2015c) of the war scenario in which Brazil is located.

Here, perhaps, is one of the most significant elements of this movement as a challenge shared by the proposals of resistance: to abandon the planning of the meanings attributed to the category of women and their demands; a multiple investment of desire that breaks the fixity of identity and recognizes the fuel of political action in the plurality of demands. Through \#EleNão [\#NotHim] the deep contaminations that unfold beyond the homogeneous meanings of the sex/gender relation are exposed, pulverizing gender in deterritorialized subversive invests of resistance. ${ }^{19}$

\section{Final considerations}

The movements that forge the feminist struggles of Latin America have, among many characteristics, a transversal collective appeal that dialogues with several other political demands by right. Not by change, in Brazil, feminist movements are consolidated by a plurality of dialogues with other specific issues such as the indigenous women's movement and the land rights of the indigenous peoples, the dam-affected women's movement, which seeks to reclaim land expropriated by State for the construction of large enterprises and the catastrophes that involved such constructions, as well as the women affected by the mega events in Brazil, such as the World Cup and the Olympics, through the demand for a fair housing after the forced evictions to carry out the renovations.

Among so many demands, what appears as contamination of these fronts of action is that the bodies and lives of women, with each new action produced by the neoliberal rationalities (Gago 2014), are pushed with greater intensity to the precariousness as tool of governmental precarization (Lorey 2015).

This implies that the claim of guardianship through the penal system to protect against domestic and sexual violence suffered by women and girls is one of the elements that

\footnotetext{
19 This analysis of the "new contours" of the feminist struggles in Brazil cannot be taken as arising from the process of election of Bolsonaro and the movement \#EleNão [\#NotHim]. These struggles have already surfaced substantially in the Brazilian scenario since 2015. However, this connection between the occupation of the streets by women's bodies and the new senses of feminist action undoubtedly have a broad projection of the micropolitics that have been operating daily in Brazil, revitalizing the urgency of new looks and new possibilities of shared political struggle.
} 
forge the multiplicity of meanings of the feminist positions as a strategy of politicalsocial transformation.

In this sense, to restrict the criminological criticism, taken by the gender debates, to the reaction of criminal policies, is to empty the power involved in the collective reflection that permeates the possibilities of constructing new ways of thinking the feminist practices like theories that are propellers of a really subversive criminology.

Here, to answer the questions formulated to the present work: a) How do these connections and ambivalences affect feminist criminology, but, in particular, how do these ambivalences affect subjects in criminology, as subjects of violence, activists and researchers? b) How are digital tools being used as strategic elements against gender violence? c) How is "hashtag activism" responsible for building bonds between women, creating networks of mutual support and strengthening their awareness of social and legal rights?, we propose to redirect the readings of feminist criminology in Brazil, which have been specifically articulated through the criminalization of violence, for a more comprehensive reading in which feminist strategies - here based on technologies - are the starting point for affirming policies of solidarity and coping with women's vulnerabilities.

In this sense, we propose to redirect the Brazilian readers about gender-based violence to an enabling a rearrangement of the political struggles organized by women and the social rights of "minority" groups as a radical node of theoretical production and real confrontation with the feminist demands shared by cells of struggle, strategic alliances of solidarity.

Thus, by analyzing the hashtags exposed here, one cannot only question the punitive rationalities involved in the production of these debates, but how they can, based on the recognition of their own limitations and the conflicts inherent in all forms of political struggle, serve as support to understand new organizations and new ways of producing subjectivity.

The punitive power has been responding to feminist struggles with a certain coparticipation. That is, the feminist struggles for rights in Brazil are associated with the criminalization of conducts and behaviors, dialoguing with the claims that have been made. In the context described here, it can be seen through the criminalization of "sexual harassment" and its instrumentalization for the production of more severe legislation and for the co-optation of these demands by the State. An example of this state reinforcement through feminist claims can be perceived in the new criminal procedural modality that makes it impossible to quit criminal prosecution in case of sexual violence.

However, we can note that digital strategies are being used not only for build bonds between women, creating networks of mutual support and strengthening their awareness of social and legal rights, but also to reformulate a language that is not linked to the semantics of punishment.

This assertion consists in realizing that the hashtags \#ChegaDeFiuFiu [\#NoMoreCatCalling] and \#MyPrimeiroAssedio [\#MyFirstHarassment], despite carrying narratives linked to the strategies of punishment, were constituted prioritizing to reverberate solidarity. Also, from these movements, others began to develop in order to denaturalize the daily violence - political and social - and strengthen solidarity 
connections between women taking as a common point the rejection of violence against vulnerable groups, in the case of \#MeuAmigoSecreto [\#MySecretFriend], and especially, \#EleNão [\#NotHim].

That is, the collective construction processes that produced them looked for contaminations that have brought the anti-punitivist debates to feminist struggles, seeing, with each new step taken by the movements, a new demonstration of the reinforcement to the perception of the limits and the problems that involve the punitive power as emancipation.

In Brazil, feminist movements have been very close to the claim of rights policies and, even, representation by rights through criminal law. The modulation of the debates of feminist criminology in Brazil is appropriate in this language and especially dialogues with the issues of women victims of domestic violence or placed as perpetrators of crimes.

Feminist movements in Brazil - or so recognized - have understood that the configuration of criminalizing practices are mechanisms for the protection of women's rights, so it is through this encounter between critics of criminology and feminist movements that feminist criminology is going to be constituted as a knowledge that understands punishment as a valid strategy. So, rethinking these strategies has been a demand of the incarcerated women's movements and the mothers and family members who have lost their children to declare violence - especially by the police. Thus, the very configurations of the language of feminist movements have pointed out that they are no longer satisfied with the demands of criminalization.

To think about this reconfiguration of feminist struggles for rights and justice requires rethinking criminology, remembering that punishment is a reinforcement of the agencies that constitute misogynist and racist violence (Sudbury 2002, 2004).

The idea of introducing hashtags as a new possibility of reading the criminological field itself is to re-read feminist criminology and to appropriate the new contours made available by the digital fronts as a way of removing criminalization as a center of concern, especially in view of what has already been built as a critique of punitive power and its implication in the bodies of women, LGBTQIA+, Black people, indigenous people and so on.

In the first movements presented here, we may realize that there is a claim of the victim's position, even if the claim of that position is announced as an emancipatory possibility. However, this proposal implies demands of punishment and a place without agency. However, it seems that the contaminations that are stimulating other ways of claiming a sense of justice to the vulnerable groups starts to dispense this language, especially through \#NotHim, in assuming the sharing of violence that is imposed on marginalized groups, the debate constitutes an extension of political claims for Justice and for another political form in Brazil.

Through collective denunciations, shared by the implication of the "I" - especially the hashtag \#MeuAmigoSecreto [\#MySecretFriend], the displacement of individualized denunciations, the hallmark of punitive spectra, is reallocated to capillary scattered narratives that, for diverse reasons, share a mesh of claims for change: behavior, laws 
and politics. Moreover, these practices dispute the imaginary, not only by repositioning, but also by the possibility of thinking beyond the "available alternatives".

The construction of \#EleNão [\#NotHim], by personalizing in Bolsonaro what one does not want, pollinates cells that forge the vital force of the production of new lives in respecting those that are violated by the representative figure of the State. Therefore, pointing out the challenges involved in such categories is only possible through networks of solidarity that seek the goal of fighting for life - for all life, questioning naturalized expressions such as democracy, freedom, solidarity, respect, rights and the very idea of life. This collective construction that has occupied the streets of Brazil and the world makes it clear that there are radical ways of operating "hashtag activism", which may be responsible for building real bonds between women, creating networks of mutual support and strengthening their awareness of social and legal rights.

Feminisms have deeply re-articulated how to expose the limitations not only of a subject and its representation, but how, successfully, those terms captured by necropolitical meanings (Mbembe 2011) can be subverted to germinative potentials. Therefore, recognizing what is liable to produce subjectivities that do not trade with the precariousness of other bodies, of other lives, is the first task to produce an analysis of the priority strategies in this struggle for another possible world.

In this sense, as Rolnik explains, not negotiating the non-negotiable is to remove

everything that hinders the affirmation of life, in its essence of creative power. To learn to distinguish it from the negotiable one: everything that could be accepted and readjusted because it does not weaken the instituting vital force, but instead generates the objective conditions for an event to occur, thus fulfilling its ethical destiny. (Rolnik 2018, p. 197)

Rethinking coping tactics and refocusing views is a permanent task, not only to reveal the punitive meanings that are present, the primary obstacle to affirmation of life in these paths, but especially to understand that stereotypes of victim and author are effects of biopolitics that forge subjectivities of extermination naturalized by their performance.

As the call of the Argentine collective "Ni Una Menos" [Not One Less] for the global feminist strike of March 8, 2019, "alive, free and without debt we want ourselves". Traces that call for the subversion of this world, in which distribution of lethality, imprisonment and indebtedness are articulated with close and inseparable complicity. Through new meanings in which it is no longer accepted that "discourse is moderate", but always reshaped by the urgency of new resonances (Coletivo Ni Una Menos 2019), there is an announcement of criminologies and critical thinking, ever feminist, committed by the radical nature of creation.

Finally, constructing the criticism of tactics and the very conceptions of abuse allegations - or "harassment", is also to multiply the exposure that abusive practices are abuses of power. Such daily violence in interpersonal, political, work, study and other relations must be transformed by collective denunciations, thus marked by the plurality of points in which hierarchies are found. Only then is it possible to project possibilities beyond the academic debates that translate into an abolitionist penal transference in dialogue with reality and articulated by the unimaginable, moving away the pacts of silence and tolerance to the unequal relations that cross its construction. 


\section{References}

Alexander, M., 2017. El color de la justicia: La nueva segregación racial en Estados Unidos. New York/London: The New Press.

Alimena, C., 2010. A tentativa do (im)possível: feminismos e criminologias. Dissertação, Mestrado em Ciências Criminais. Porto Alegre: Pontifícia Universidade Católica do Rio Grande do Sul.

Alves, D., 2017. Rés negras, juízes brancos: Uma análise da interseccionalidade de gênero, raça e classe na produção da punição em uma prisão paulistana. Revista CS [online], 21, pp. 97-120. Available from: https://doi.org/10.18046/recs.i21.2218 [Accessed 8 September 2020].

Amaral, A., 2018. Neoliberalismo e democracia que resta: Uma análise desde o caso brasileiro / Neoliberalism and democracy that remains: an analysis from the brazilian case. Profanações [online], 5(2), pp. 129-146. Available from: https://doi.org/10.24302/prof.v5i2.2000 [Accessed 8 September 2020].

Arduino, I., 2018. Entre la victimización opresiva y la justicia emancipatoria: Articulaciones entre feminismo y justicia penal. In: I. Lorey et al., eds., Los feminismos ante el neoliberalismo. $1^{\text {st }}$ ed, Adrogué: La Cebra.

Batista Jr., J., 2019. Não é vitimismo. Veja [online], 22 February. Available from: https://veja.abril.com.br/brasil/nao-e-vitimismo / [Accessed 15 February 2019].

Borges, J., 2017. O que é encarceramento em massa? São Paulo: Letramento.

Brum, E., 2019. O homem mediano assume o poder: o que significa transformar o ordinário em "mito" e dar a ele o Governo do país? El País Brasil [online], 2 January. Available from: https://brasil.elpais.com/brasil/2019/01/02/opinion/1546450311 448043.html [Accessed 5 February 2019].

Brunelli, C., 2018. Como se formou o grupo de 800 mil mulheres contra Bolsonaro no Facebook. Universa [online], 12 September. Available from: https://www.uol.com.br/universa/noticias/redacao/2018/09/12/mulheres-contrabolsonaro-nas-redes-especialista-ve-impacto-nas-urnas.htm?cmpid=copiaecola [Accessed 8 September 2020].

Butler, J., 1990. Gender Trouble. New York: Routledge.

Butler, J., 2015a. Quadros de Guerra: Quando a vida é passível de luto. Trans.: S. Lamarão, A. M. da Cunha. Rio de Janeiro: Civilização Brasileira.

Butler, J., 2015b. Relatar a si mesmo: Crítica da violência ética. Trans.: R. Bettoni. Belo Horizonte: Autêntica.

Butler, J., 2015c. Repensar la vulnerabilidad y la resistencia. Conference. Alcalá de Henares: Simposio de la Asociación Internacional de Filósofas (IAPh), 24 June.

Butler, J., 2017. Cuerpos aliados y lucha política: Hacia una teoría performativa de la asamblea. Trans.: M.J. Viejo. Madrid: Paidós. 
Campos, C.H., 1998. O discurso feminista criminalizante no Brasil: Limites e possibilidades. Dissertação, Mestrado em Direito. Programa de Pós-Graduação em Direito. Florianópolis: Universidade Federal de Santa Catarina.

Campos, C.H., 2003. Juizados Especiais Criminais e seu déficit teórico. Revista Estudos Feministas [online], 1(11), 155-170. Available from: https://doi.org/10.1590/S0104026X2003000100009 [Accessed 8 September 2020].

Carneiro, S., 2005. A construção do outro como não-ser como fundamento do ser. Tese. Doutorado em Educação. Universidade de São Paulo.

Castilho, E., 2016. As diretrizes nacionais para investigação do feminicídio na perspectiva de gênero. Sistema Penal \& Violência [online], 8(1), pp. 93-106. Available from: https://doi.org/10.15448/2177-6784.2016.1.23899 [Accessed 8 September 2020].

Celmer, E., 2008. Feminismos, discurso criminológico e demanda punitiva: uma análise do discurso de integrantes das organizações não-governamentais Themis e JusMulher sobre a Lei 11.340/06. Dissertação, Mestrado em Ciências Criminais. Porto Alegre: Pontifícia Universidade Católica do Rio Grande do Sul.

Coletivo Ni Una Menos, 2019. Convocatória para a paralisação feminista 8M 2019. Mídia Ninja [online], 17 January. Available from:

http://midianinja.org/news/convocatoria-para-a-paralisacao-feminista-8m-2019/ [Accessed 1 April 2019].

Collins, P.H., 2016. Aprendendo com a outsider within*: a significação sociológica do pensamento feminista negro. Sociedade e Estado [online], 31(1), pp. 99-107. Available from: https://doi.org/10.1590/S0102-69922016000100006 [Accessed 8 September 2020].

Comité Invisible., 2017. Ahora. Trans.: D.L. Sanromán. Logroño: Pepitas.

Crenshaw, K., 1991. Mapping the Margins: Intersectionality, Identity Politics, and Violence Against Women of Color. Stanford Law Review [online], 43(6). Available from: https://doi.org/10.2307/1229039 [Accessed 8 September 2020].

Davis, A., 1997. Race and Criminalization: Black Americans and the Punishment Industry. In: W. Lubiano, ed., The House That Race Built. New York: Pantheon, pp. 264-279.

Davis, A., 2016. Mulheres, raça e classe. Trans.: H.R. Candiani. São Paulo: Boitempo.

Davis, A., 2017. La libertad es una batalla constante: Ferguson, Palestina y los cimientos de un movimiento. Trans.: E. Odriozola, A. Reyes and L. Gómez. Madrid: Capitán Swing.

Debert, G., Gregori, M.F., and Piscitelli, A., eds., 2006. Gênero e Distribuição da Justiça: As delegacias de defesa da mulher na construção das diferenças. Campinas: Pagu/Unicamp.

Despentes, V., 2016. Teoria King Kong. Trans.: M. Bechara. São Paulo: n-1.

Flauzina, A, 2016. O feminicídio e os embates das trincheiras feministas. Revista Discursos Sediciosos: Crime, Direito e Sociedade 20(23/24), pp. 95-106. 
Flauzina, A., 2008. Corpo negro caído no chão: O sistema penal e o projeto genocida do Estado brasileiro. Rio de Janeiro: Contraponto.

Foucault, M., 1996. História da Sexualidade I: A vontade de saber. Trans.: M.T.C. Albuquerque and J.A.G. Albuquerque. Rio de Janeiro: Graal.

Fraser, N., 2000. De la redistribuición al reconocimiento? Dilemas de la justicia em la era "postsocialista". In: N. Fraser and J. Butler, ¿Reconocimiento o redistribución?: Un debate entre marxismo y feminismo. Trans.: M. Malo de Molina Bodelón and C. Vega Solís [online]. Madrid: Traficantes de Sueños. Available from:

https://www.traficantes.net/sites/default/files/pdfs/documentos nlr 3 web 0.pdf [Accessed 8 September 2020].

Gago, V., 2014. La razón neoliberal: Economías barrocas y pragmática popular. $1^{\text {st }}$ ed. Buenos Aires: Tinta Limón.

Godoi, R., 2016. Penar em São Paulo: Sofrimento e mobilização na prisão contemporânea. Revista Brasileira de Ciências Sociais [online], 31(92), pp. 1-18. Available from: http://dx.doi.org/10.17666/319212/2016 [Accessed 8 September 2020].

Haraway, D., 2002. O Manifesto Ciborgue: a ciência, a tecnologia e o feminismo socialista nos finais do século XX. In: A.G. Macedo, ed., Género, identidade e desejo: Antologia Crítica do Feminismo Contemporâneo. Lisboa: Cotovia.

hooks, b., 2000. Feminist Theory: From Margin to Center. Boston: South End Press.

Jarrin, A., and Caldwell, K.L., 2018. Beyond \#MeToo, Brazilian women rise up against racism and sexism. The Conversation [online]. Available from:

https://theconversation.com/beyond-metoo-brazilian-women-rise-up-againstracism-and-sexism-89117 [Accessed 1 March 2020.]

Lorey, I., 2015. State of Insecurity: Government of the Precarious. Brooklyn, NY/London: Verso.

Maia, I., 2019. Um monstro chamado Judith Butler. LavraPalavra [online], 27 February. Available from: https://lavrapalavra.com/2019/02/27/um-monstro-chamadojudith-butler-2/ [Accessed 27 February 2019].

Martinelli, A., 2018. Documentário "Chega de Fiu Fiu” é muito mais do que um retrato do assédio nas ruas. Huffpost Brasil [online], 15 May (updated 31 January 2019). Available from: https://www.huffpostbrasil.com/2018/05/15/documentario-chegade-fiu-fiu-e-muito-mais-do-que-um-retrato-do-assedio-nasruas a 23435382/?guce referrer us=aHR0cHM6Ly93d3cuZ29vZ2xlLmNvbS8\&g uce_referrer_cs=-mo8-IXWvtM6ARdM8wDCDw\&guccounter=2 [Accessed 8 September 2020].

Mbembe, A., 2011. Necropolítica. Trans.: E. Falomir Archambault. Santa Cruz de Tenerife: Melusina.

Meirelles, F.S., 2018. 29ํㅗ Pesquisa Anual do Uso de TI [online]. Presentation. Available from: https://eaesp.fgv.br/ensinoeconhecimento/centros/cia/pesquisa [Accessed 10 February 2019]. 
Mendes, S., 2014. Criminologia Feminista: Novos paradigmas. São Paulo: Saraiva.

Montenegro, M., 2015. Lei Maria da Penha: Uma análise criminológico-crítica. Rio de Janeiro: Revan.

Padrão, M., 2015. Como surgiu o \#meuamigosecreto com denúncias de machismo na web. UOL [online], 25 November. Available from:

https://www.uol.com.br/tilt/noticias/redacao/2015/11/25/entenda-como-surgiu-omeuamigosecreto-com-denuncias-de-machismo-na-web.htm [Accessed 8 September 2020].

Peroni, C., and Rodak, L., 2018. The fourth wave of feminism: from sisterhood and social networking towards a new citizenship? Description of the meeting. Oñati International Institute for the Sociology of Law [online], 14-15 June. Available from: http://www.iisj.net/en/workshops/fourth-wave-feminism-sisterhood-and-socialnetworking-towards-new-citizenship [Accessed 1 June 2019].

Portal Catarinas, 2018. O grito \#EleNão ecoa na maior manifestação de mulheres da história do país. Catarinas [online], 30 September. Available from:

https://catarinas.info/o-grito-elenao-ecoa-na-maior-manifestacao-de-mulheres-dahistoria-do-pais/ [Accessed 8 September 2020].

Potter, H., 2018. A trajetória política de Jair Bolsonaro. Carta Capital [online], 26 October. Available from: https://www.cartacapital.com.br/politica/a-trajetoriapolitica-de-jair-bolsonaro/ [Accessed 8 September 2020].

Prando, C., 2017. O caso do ônibus e a seletividade dos penalistas. Empório do Direito [online], 2 September. Available from: https://emporiododireito.com.br/leitura/ocaso-do-onibus-e-a-seletividade-dos-penalistas [Accessed 19 February 2019].

Prata, A., 2015. \#primeiroassédio foi fundamental. \#agoraéquesaoelas foi lindo. Agora, esse \#meuamigosecreto... [Facebook post]. Facebook [online], 25 November.

Available from:

https://www.facebook.com/antonio.prata.18/posts/986325001427624?pnref=story [Accessed 8 September 2020].

Preciado, P.B., 2011. Multidões queer: notas para uma política dos "anormais". Estudos Feministas [online], 19(1), 312. Available from: https://doi.org/10.1590/S0104026X2011000100002 [Accessed 8 September 2020].

PV Mulher, 2015. Hashtag Transformação: 82 mil tweets sobre o \#PrimeiroAssedio. PV Mulher [online], 30 October. Available from: https://pvmulher.com.br/hashtagtransformacao-82-mil-tweets-sobre-o-primeiroassedio/ [Accessed 9 September 2020].

Rago, M., 2014. O feminismo acolhe Foucault. Labrys. Revista Eletrônica Estudo Feministas [online], Julho/Dezembro. Available from:

https://www.labrys.net.br/labrys26/foucault/margaok.htm [Accessed 8 September 2020].

Reis, P.D., 2019. Criminalização e extermínio da juventude preta e periférica: a seletividade legislativa e a guerra às drogas. In: A. Gostinski, C. Bispo and F. 
Martins, eds., Estudos feministas por um direito menos machista (vol. 4).

Florianópolis: Tirant lo Blanch.

Rolnik, S., 2018. Esferas da insurreição: Notas para uma vida não cafetinada. São Paulo: n-1.

Safatle, V., 2015. O circuito dos afetos. São Paulo: Cosac Naify.

Safatle, V., 2017. Só mais um esforço. São Paulo: Três Estrelas.

Santos, T., ed., 2017. Levantamento nacional de informações penitenciárias INFOPEN Mulheres. [online]. $2^{\text {nd }}$ ed. Brasília: Ministério da Justiça e Segurança Pública, Departamento Penitenciário Nacional. Available from: https://www.justica.gov.br/news/ha-726-712-pessoas-presas-nobrasil/relatorio_2016 junho.pdf [Accessed 8 September 2020].

Sayak, V., 2010. Capitalismo gore. Santa Cruz de Tenerife: Melusina.

Shiach, M., 1989. “O 'simbólico' deles existe, detém poder - nós, as semeadoras da desordem, o conhecemos bem demais". In: T. Brennan, ed., Para além do falo: Uma crítica a Lacan do ponto de vista da mulher. Trans.: A. Xavier. Rio de Janeiro: Rosa dos Tempos.

Souza, L.T., 2016. Da expectativa à realidade: A aplicação de sanções na Lei Maria da Penha. $1^{\text {st }}$ ed. São Paulo: Lumen Juris.

Spivak, G., 1997. Estudios de la Subalternidad: Deconstruyendo Ia Historiografía. In: S. Rivera Cusicanqui and R. Barragán, eds., Debates post coloniales: Una introducción a los estudios de la subaltenidad. La Paz: Aruwiyiri/Historias, Rotterdam: Sephis.

Spivak, G., 2010. Pode o subalterno falar? Trans.: S.R.G. Almeida, M.P. Feitosa and A.P. Feitosa. Belo Horizonte: UFMG.

Stanley, E., and Smith, N., eds., 2011. Captive Genders: Trans Embodiment and the Prison Industrial Complex. Oakland: AK Press.

Sudbury, J., 2002. Celling Black Bodies: Black Women in the Global Prison Industrial Complex. Feminist Review [online], 70(1), pp. 57-74. Available from: https://doi.org/10.1057/palgrave/fr/9400006 [Accessed 8 September 2020].

Sudbury, J., 2004. A World Without Prisons: Resisting Militarism, Globalized Punishment, and Empire. Social Justice, 31(1-2), pp. 09-30.

The Critical Resistance-Incite!, 2008. Statement on gender violence and the prison-industrial complex [online]. Available from: https://incite-national.org/wpcontent/uploads/2018/08/CR-INCITE-statement-2008discussion.pdf [Accessed 1 March 2020].

Think Olga, 2015. Hashtag Transformação: 82 mil tweets sobre o \#PrimeiroAssedio [Facebook post]. Facebook [online], 26 October. Available from: https://www.facebook.com/thinkolga/photos/hashtagtransforma\%C3\%A7\%C3\%A3o-82-mil-tweets-sobre-o-primeiroassedioleia-nossaan\%C3\%A1lise-so/695924083876449/ [Accessed 9 September 2020].

Think Olga, 2018. Campanha Chega de Fiu Fiu. Think Olga [online]. Available from: https://thinkolga.com/projetos/chega-de-fiu-fiu/ [Accessed 9 September 2020]. 
Uchoa, P., 2018. Jair Bolsonaro: Why Brazilian women are saying \#NotHim. BBC News [online], 21 September. Available from: https://www.bbc.com/news/world-latinamerica-45579635[Accessed 1 March 2020].

Zaffaroni, E.R., 2013. A questão criminal. Rio de Janeiro: Revan. 